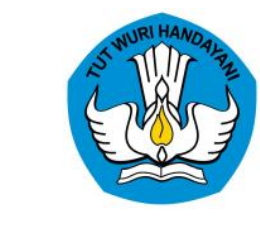

Check for updates

\title{
ISLAMICIZATION STRATEgIES IN KAO ANCIENT Village, NORTH HALMAHERA
}

\author{
Wuri Handoko ${ }^{1}$, Muhammad Al Mujabuddawat (D) 1 *, Joss Whittaker ${ }^{2}$ \\ ${ }^{1}$ Balai Arkeologi Maluku \\ Jl. Namalatu-Latuhalat, Ambon 97118, Indonesia \\ ${ }^{2}$ Department of Anthropology, University of Washington \\ Seattle, WA 98195-3100, United States \\ *mujab@kemdikbud.go.id
}

\begin{abstract}
The Kao Ancient Village settlement site is located in the hinterland of North Halmahera, standing on relatively wet ground flanked by the river Aer Kalak, Ake Ngoali, and Ake Jodo and surrounded by sago and swamp forests. The settlement conditions on the site make it limited for residential space, but a community of Kao people settled in this area for a relatively long period of time between 100-200 years and even recorded in history that Kao region is the main food supplier for Ternate in the past. This research conducted surface surveys and limited excavations, then mapped the areas of artifactual findings, and identified patterns of spatial use by analyzing surface features and artifact scatters. Variety of archeological data both artifacts and oral traditions are then analyzed guided by relevant reference sources. The results show that Kao Site is an advanced settlement and has a significant role as the center of Islamicization in Halmahera. The Kao people settled for a long time in one location supported by water sources and the potential of farming lands making the Kao area a part of bustling trade networks. Kao became part of a strategy in spreading Islam to other inland areas, as well as coastal areas in North Halmahera.
\end{abstract}

Keywords: Kao; North Halmahera; archaeology; Islamicization; Islam conversion

\section{INTRODUCTION}

Archaeological evidence, oral tradition, and written historical records suggest that the Kao Ancient Village Site in northern Halmahera was an early center of Islamicization. It serves as a remarkable example of the entry of Islam into the Northern Moluccas. Specifically, the site shows changing cultural practices which, we argue, were at least partially responsible for encouraging Islam's spread in Halmahera. While a religion's ideology may play a role in propagating it, evidence from Kao suggests that the cultural practices associated with the same religion are equally significant, or perhaps more so. The extent to which the cultural practices of a new religion benefit a community that adopts it, and the extent to which the new religion's cultural practices can adapt to a context of pre-existing practice, may account in part for how rapidly and securely the new religion establishes itself. This appears to be the case in Kao, on the benefits side, the arrival of Islam appears to have coincided with a marked increase in trade. In terms of adaptation, the remains of buildings and burials at Kao indicate that the form of Islam which took hold in Kao worked alongside established cultural practices.

\section{Theoretical Background}

Scholars of Islamicization in Island Southeast Asia also ask how Islam came to be accepted and practiced by political leaders and large numbers of their followers. Two basic models of adoption guide these questions. One is a top-down model, in which political leaders drive the large-scale conversion of their followers, while the alternative model proposes a ground-up process, whereby political leaders converted only when sufficient numbers of their subjects were already Muslim. Within these frameworks, there has been considerable debate about the relative role of political Islam and Sufism in relation to the degree to which new Islamic ideas were understandable and sensible to south-east Asians and their diverse pre-existing belief systems (Lape, 2000a; Lape, 2000b; Reid, 1993; Reid, 1995). 
Carvajal (2013), proposes to investigate Islamicization as a two-fold phenomenon, which encompasses both the adoption of a belief system, and the adoption of cultural practices associated with that belief system. Although the former change is difficult to detect in the material record, the latter is visible to archaeologists. By detecting changes in social practice in the archaeological record, one can sometimes infer changes in belief systems, yet changes in social practice are worth studying in their own right. Changes in cultural practice are not only closer to people's everyday lives than changes in ideology or ritual; they also tend to exert more of an influence on the archaeological record. In this vein Insoll (2001; 2003: 14-22) suggests that an archaeology of Islam should focus not only on charismatic remains such as mosques, tombs, and inscriptions, but also include things that affect daily life, such as diet, dress, domestic architecture, landscaping, and settlement patterns.

While the ideology behind changes in social practice may remain inaccessible, the changes in social practice themselves may be the driving force behind the acceptance of a new religion, especially when a community adopts a religion or other ideology from outside their previous experience. In many cases, the ideology in question is less relevant for the adopters than the social changes that come along with it. For example, Graham, Simmons, \& White (2013) have argued that the readiness of some Mayan elites to adopt Christianity during Spanish colonial period involved not only the degree to which Christianity accorded with earlier Mayan cosmology, but also pragmatic recognition that Christianity sanctioned an advantageous set of norms regarding warfare. Whether the new religion's social practices drove its adoption, or whether the ideology itself was sufficiently attractive, the social practices tend to leave more of a trace in the archaeological record, and so serve as an appropriate subject of investigation.

Further, the archaeological evidence of changing social practices can provide a more nuanced picture of changes in a society as people in it adopt a new religion. While written history tends to emphasize the perspective of dominant classes, and oral tradition may be similarly biased, the archaeological record reflects patterns of human activity (albeit interpreted by archaeologists) rather than a particular perspective. Such is the case in

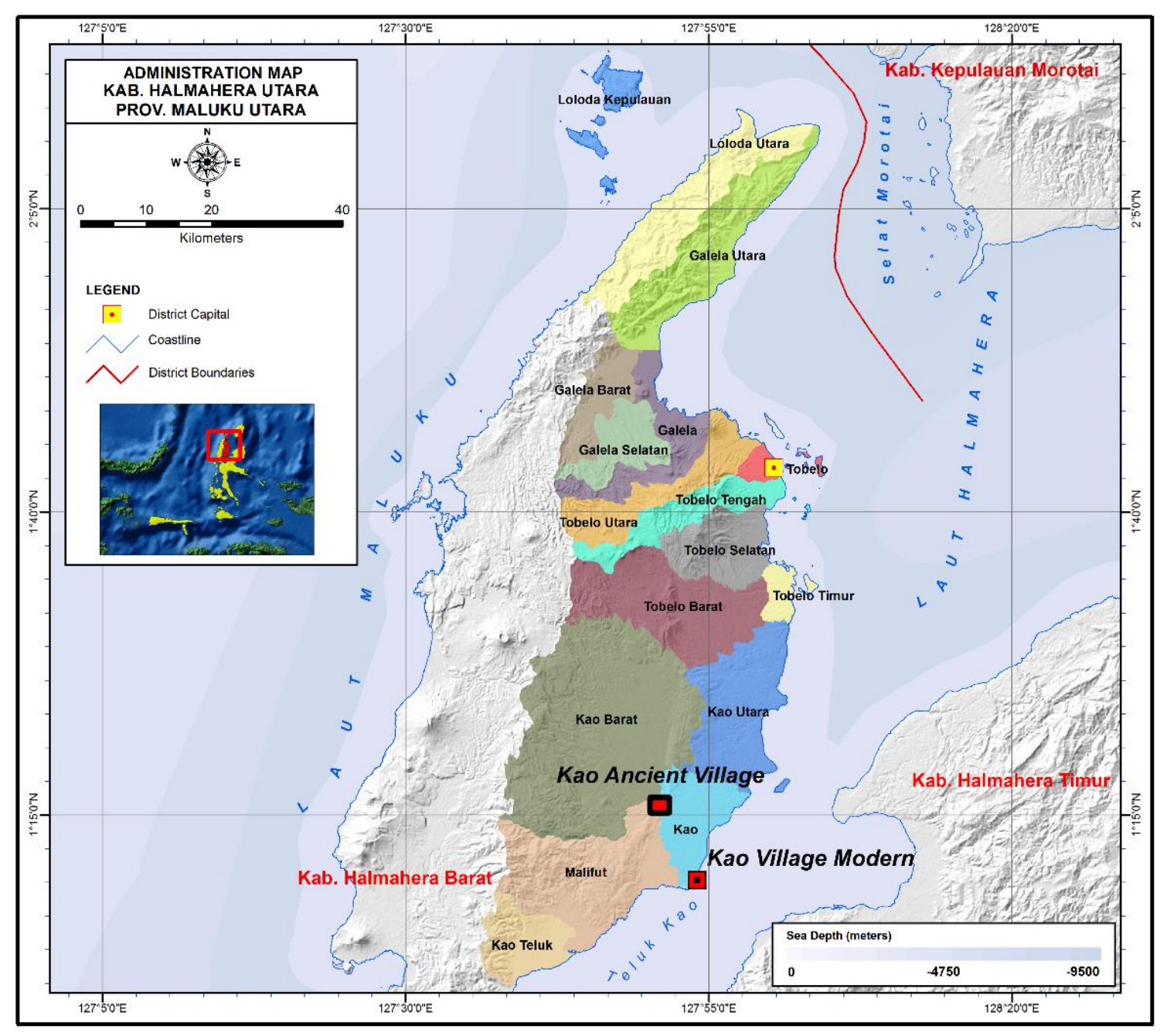

Figure 1. Site location

(Source: Balai Arkeologi Maluku, 2018) 
Kao, where archaeological evidence suggests an adaptation and negotiation between Islamic social practices and those that preceded them.

\section{The Site: its Location and History}

Oral traditions tell us that the Kao Ancient Village was first inhabited in the 16th century A.D., and abandoned due to forced relocation in the late $19^{\text {th }}$ or early $20^{\text {th }}$ century (Handoko, 2017; Handoko \& Mujabuddawat, 2017b; Handoko \& Mujabuddawat, 2017a). The site is located in the hinterland of North Halmahera, at the confluence of the rivers Aer Kalak and Ake Ngoali, where they merge to form the river Ake Jodo. The Kao site's environment comprises swampy areas, watershed, and lush rice paddies made fertile by the volcanic sediment of the Gamkonora volcanic eruption (Campen, 1883: 54; Leirissa, 1990: 111). The broad, navigable Ake Jodo River that extends to the coast of North Halmahera is an entrance for migrants and foreign traders (Handoko \& Mujabuddawat, 2017b).

The settlement's population was not dependent on a single food source. In addition to rice, sago (Metroxylon sagu) was and is abundant in the area surrounding the site. According to oral traditions, sago swamp comprised up to 65,000 hectares of the land around Kao (Handoko et al., 2016; Handoko, 2017: 103; Tim Penelitian, 2014). The historical record suggests Kao produced enough of a surplus to supply the island of Ternate with the sago and rice necessary to support its population, from which it was known as the rice barn of Ternate (Amal, 2010; Leirissa, 1990: 110; Naping, 2013). Today, sago farming is still an important staple and cash crop for the Kao peoples. As in the past, they process sago both for their own use and for export. Today, sago processing in Kao has been centralized in a plant near the archaeological site.

While the site today is no longer occupied, it remains significant in the genealogies and topogenesis of communities throughout north Halmahera, especially Tobelo and Galela, as a point of origin (Amal, 2010; Handoko \& Mujabuddawat, 2017b: 156-157; Leirissa, 1990: 130; Naping, 2013). Local people claim that the

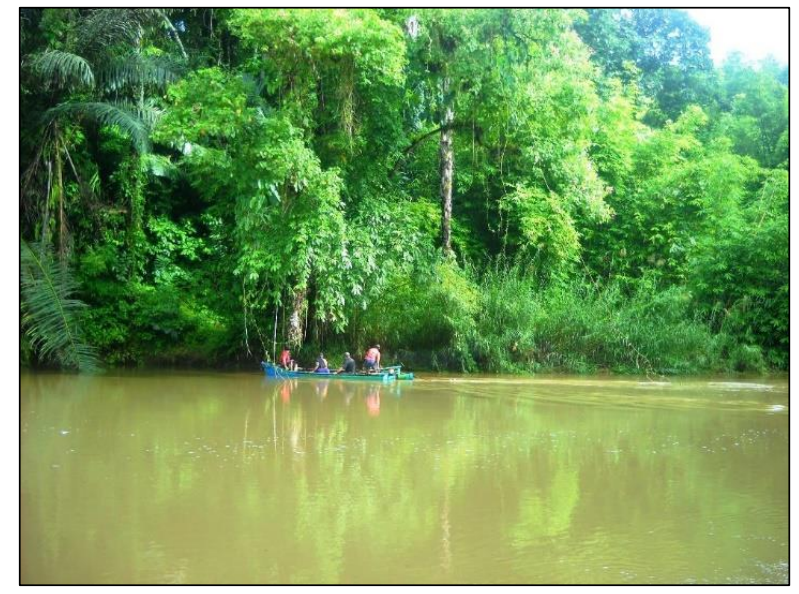

Figure 2. River branching at Kao Ancient Village (Source: Balai Arkeologi Maluku, 2016)

North Halmahera community, including Tobelo and Kao itself, originated at Telaga Lina (Lina Lake) in the Kao hinterland (Handoko \& Mujabuddawat, 2017b). Naping (2013) and Amal (2010) write that in the past, a community lived together in Telaga Lina in a large house called Hibualamo. The Tobelo peoples come from around Telaga Lina at the foot of Mount Tolo. In the past, the Tobelo people were organized into hoana (families); from this simple organization they later formed four tribes, namely Lina, Hubato, Momulate, and Gura. Telaga Lina is probably located in the upper reaches of the watersheds surrounding Kao Ancient Village. Thus, people in the Boeng, Modole, Pagu, and Tololiko regions of North Halmahera trace their origins back to the area surrounding Kao Ancent Village (Handoko \& Mujabuddawat, 2017b: 157-159). Around the 17th century, these groups began to leave their native land for the coast. At about the same time, Ternate, which exercised political power over Gamkonora, Loloda, and Jailolo, began reaching out to the settlements of the Tobelo peoples in Halmahera. Tobelo people moved to Kao land, and divided themselves into four tribes, namely Boeng, Tunai, Seleruru, and Madang. It was then that Ternate regarded Kao district as part of Ternate's territory (Amal, 2010; Handoko \& Mujabuddawat, 2017b: 156-157; Leirissa, 1990: 130; Naping, 2013).
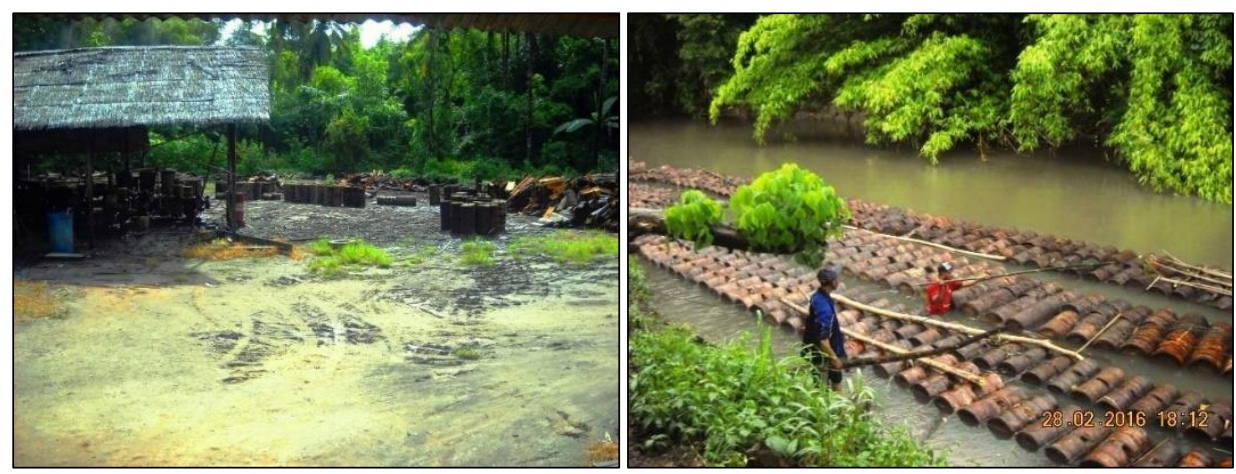

Figure 3. Sago processing plant near Kao Ancient Village Site (Source: Balai Arkeologi Maluku 2016) 


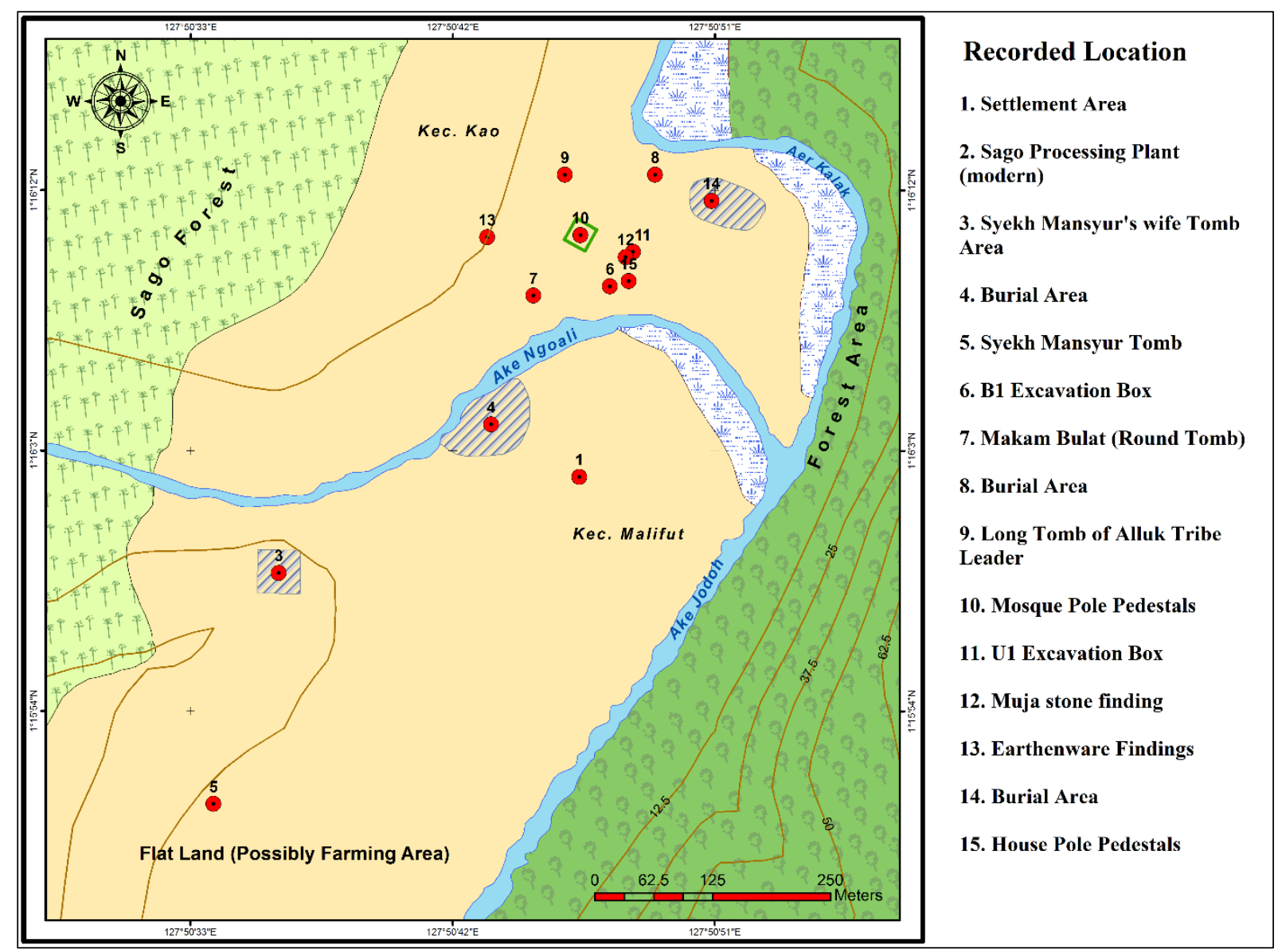

Figure 4. Spatial reconstruction of Kao Ancient Village Settlement in the past

(Source: Balai Arkeologi Maluku, 2018)

According to the same oral traditions, Kao was the first inland village in North Halmahera to embrace Islam. From Kao, Islam spread to the North Halmahera coast. This is remarkable considering the tendency in Maluku and other parts of Island Southeast Asia for coastal communities to embrace Islam before communities further inland, as oceangoing traders carried the new religion with them (Handoko et al., 2016; Handoko, 2017; Handoko \& Mujabuddawat, 2017b; Handoko \& Mujabuddawat, 2017a; Tim Penelitian, 2014). The site's location, and the opportunities for trade it provided, may explain this unusual history.

There is no evidence that the Dutch colonial government ever occupied Kao Ancient Village, but it certainly had an influence on the people who lived there, through trade and through the forced relocation that caused the site's abandonment at the turn of the twentieth century. This relocation was part of a pattern of mandatory resettlements ordered by the Dutch colonial government. The process of resettlement in almost all of the Maluku Islands was due to Colonial policies in the early 20th century that relocated villages in the inland highlands to coastal areas (De Jonge and Van Dijk, 1995). In an effort to ensure effective tax collection and oversight of the population, the Dutch ordered to residents living in upland villages to move to coastal areas during the first decade of the 20th century. In some cases of forced relocation, several villages were merged into one (De Jonge \& Van Dijk, 1995: 28-29). In the case of Kao, the exact chronology of the move is not clear. Historical sources mention a move to the Kao estuary in 1880 (Handoko et al., 2016; Handoko, 2017; Naping, 2013: 188; Tim Penelitian, 2014; van Fraassen, 1980). Oral tradition, however, states that the inhabitants moved to the estuary around 1904 (Handoko, 2017; Tim Penelitian, 2014)

Because Islam remains a well-established religion in North Maluku, and because regional oral traditions indicate Kao as a point of origin, we know the process of Islamicization to have succeeded. The question then becomes, why? This study is expected to explain the history and dynamics of the settlements on the site, related to the ideological strategy for the spread of Islam. This study emphasizes the variety of artefactual found on the site, both survey, and excavation to explain the Islamicization strategy in Kao Ancient Village in the past.

\section{METHODS}

In order to investigate the establishment, habitation, and abandonment of the Kao Ancient Village site, the research team conducted surface surveys and limited excavations. The research team mapped the areas of 
artifactual findings and identified patterns of spatial use by analyzing surface features and artifact scatters. The team collected artifacts from the surface and from excavations, paying particular attention to evidence of long-distance trade and cultural contacts. The survey also observed the natural resources available surrounding the site, especially food crops in the past and present, supported by information from interviews and site observation.

The research team used both written history and oral traditions to supplement archaeological data. Since most written history of the Moluccas up to the mid-twentieth century was written by outsiders, and those mostly Europeans, an Indigenous voice rarely emerges in written history. By incorporating oral traditions, we hope to add the perspectives of Indigenous communities. Although oral traditions are sometimes inaccurate, they are valuable as an inspiration for the formulation of archaeological hypotheses.

\section{RESULT AND DISCUSSION}

\section{Archaeological Evidence}

The investigation of social changes within a community that occurred before the beginning of written history, and beyond the living memory of that community's members, depends naturally on the study of surviving oral traditions and present social structures as a way to look backward. These lines of inquiry are relevant and irreplaceable, but also indirect. Archaeology, which looks at the past through its material remains, is a more direct way to access changes in the past, so archaeologists have long tried to infer social changes through the materials societies left behind. We can be confident that archaeology is well-equipped for this in cases such as a widespread change in social organization, which leaves unmistakable traces in the settlement constructions and distributions of wealth that survive in the ground. Archaeology is uniquely wellequipped to deal with changes in material conditions, from which social changes can often be inferred.

Island Southeast Asia has long been recognized as a region of movement and interaction (Lape, 2003), notably in the debate over the emergence of Neolithic technology there around 3,500 cal. BP (e.g. Denham, Haberle, \& Lentfer, 2004; Kayser et al., 2000; O'Connor, 2006; Szabó \& O’Connor, 2004; Terrell, 1988). This process was perhaps comparable to modern globalization in its combination of mobility and technological change (Spriggs, 2011; Tanudirjo, 2006). All Neolithic models support the great antiquity of some long-distance travel and exchange in Southeast Asia Islands, the Maluku subregion fits this pattern (e.g. Lape, 2000a; Lape, 2000b). Exchange connections proliferated over time (Ellen, 1979; Stark \& Latinis, 1992). Before European contact, far-flung, socially complex polities such as Ternate and Tidore derived political power from the control of trade (Andaya, 1991; Andaya, 1993; Andaya, 2015; Ellen, 2003; Stark \& Latinis, 1996; Swadling et al., 1996). Some established diplomatic relations with the Chinese imperial court (Ptak, 1999). Trade from mainland Asia reached the Maluku region as early as 500-600 A.D. (Lape, 2000a). The eastern region of Indonesia in the past had ports bustling with traders who then formed shipping routes from and to Sulawesi, such as the Malacca Port, Makassar, Sulu, and Maluku (Mujabuddawat, 2015: 22; Poelinggomang, L., 2002: 22). Apparently, it also deals with the trade of ceramics, which can show the origin and date.

The Kao Ancient Village Site today is dominated by wetlands and streams, and little evidence of habitation structures remains on the surface. The majority of the houses at the site were probably typical Island Southeast Asian houses made of light material, non-permanent materials or from organic materials and raised above the ground on posts. While in general it may be true that mobility correlates with lighthouses (Binford, 1990: 120). The discovery of two pole pedestals at a suspected settlement area in Kao Ancient Village supports this assumption. Two pole pedestals located in the central settlement nearby the banyan tree and the location of the mosque.

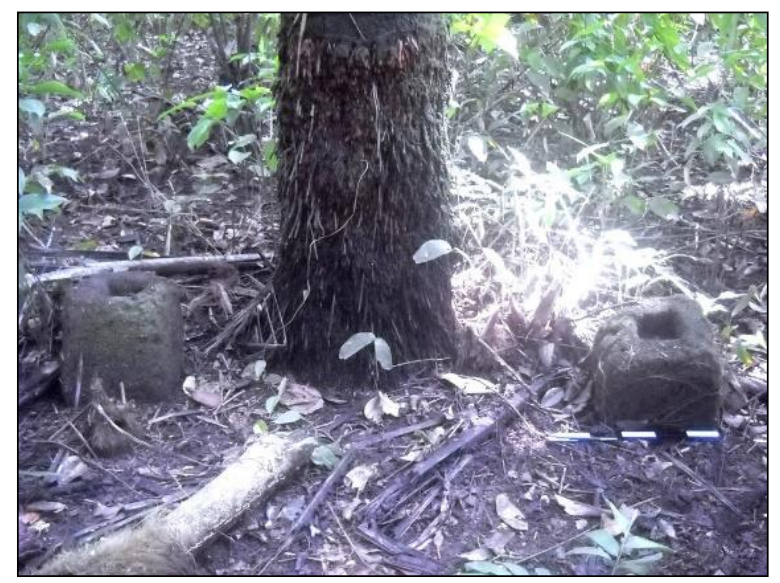

Figure 5. Pole pedestals nearby banyan tree (Source: Balai Arkeologi Maluku, 2016)

Artifact scatters are concentrated in one or two areas, previously known as Leamanggunung and Tonuo toponyms. Not far from that location, in the toponym Soa Sio, another artifact scatter is located close to a large banyan tree and a number of features including what may be a house pole pedestal. On the findings from the site, there a number of clusters space known as burial sites, mosque, and settlements which are found various types of ceramics that are estimated from 16-17th century, so that indicates Islam has developed in the Kao Ancient Village since the 16th century. A number of ceramic artifacts are found scattered over the surface and are also 


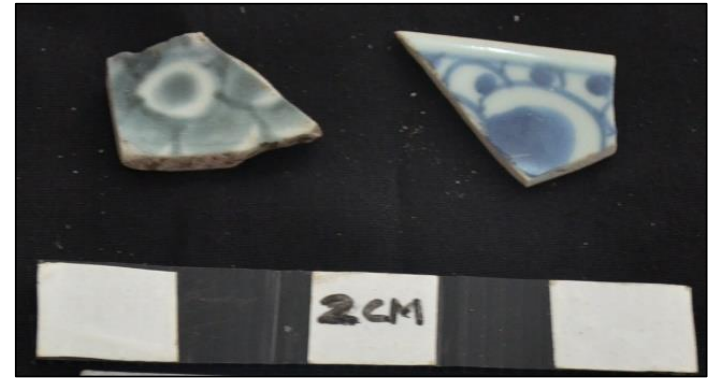

Figure 6. Ceramics finding estimated from Ming Dynasty $16^{\text {th }}$ centuries

(Source: Balai Arkeologi Maluku, 2016)

found from excavations. The findings of ceramic artifacts were identified as European ceramics from 1920th-century, Chinese ceramics from Ming Dynasty of the 16th-century and Qing Dynasty of the 18th-19th century. Based on the period of ceramics findings of the 16th and 17th centuries, it becomes an early marker of settlements and relationships with the outer regions. The distribution of ceramic findings indicates the existence of long-distance trade with the outside region, particularly with Chinese and European traders. The 1819th century was a phenomenal period, as local people have intensive contact with foreigners, and also strong relationship with other regions, both in the trading interaction and the spread of Islam is shown by the distribution of the ceramic sources (Tim Penelitian, 2014). Based on the evidence of these artifacts, it can be concluded that without having to move the settlement location, just survive in the same location, the local people can connect with people from outside, have trading interactions and cultural transmission to other inland areas along the southern and eastern coast of North Halmahera.

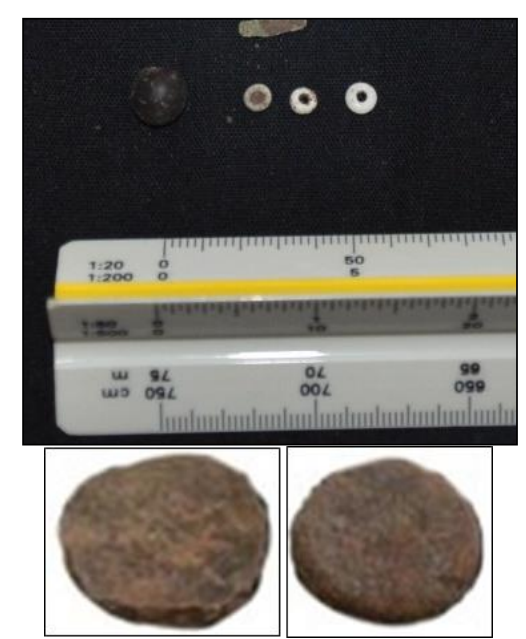

Figure 7. Beads (top) and Gacuk (down) (Source: Balai Arkeologi Maluku, 2016)

The beads' findings also indicate that commodity trading and exchanges from far areas from the Kao Ancient Village are intensive. In the meantime, there were trade links with other islands outside the Maluku archipelago and perhaps even cultural contact with traders from Java and Sumatra. Some forms and typology of the tomb show the influence of gravestones from Java and Aceh, Sumatra. The findings of the 'gacuk' game tool that is round and flat earthenware artifacts is a children's toy from Java showing evidence of Kao people interaction with Javanese in the past. In addition to relations with Ternate, a number of ceramic findings attest to long-distance trade relations with China and Europe. The findings of Chinese and European ceramics either brought directly by Chinese traders nor traders from the Maluku, Java, and Sumatra (Malay) regions, are evidence of a commercial mechanism as well as an economic network between local traders and foreign

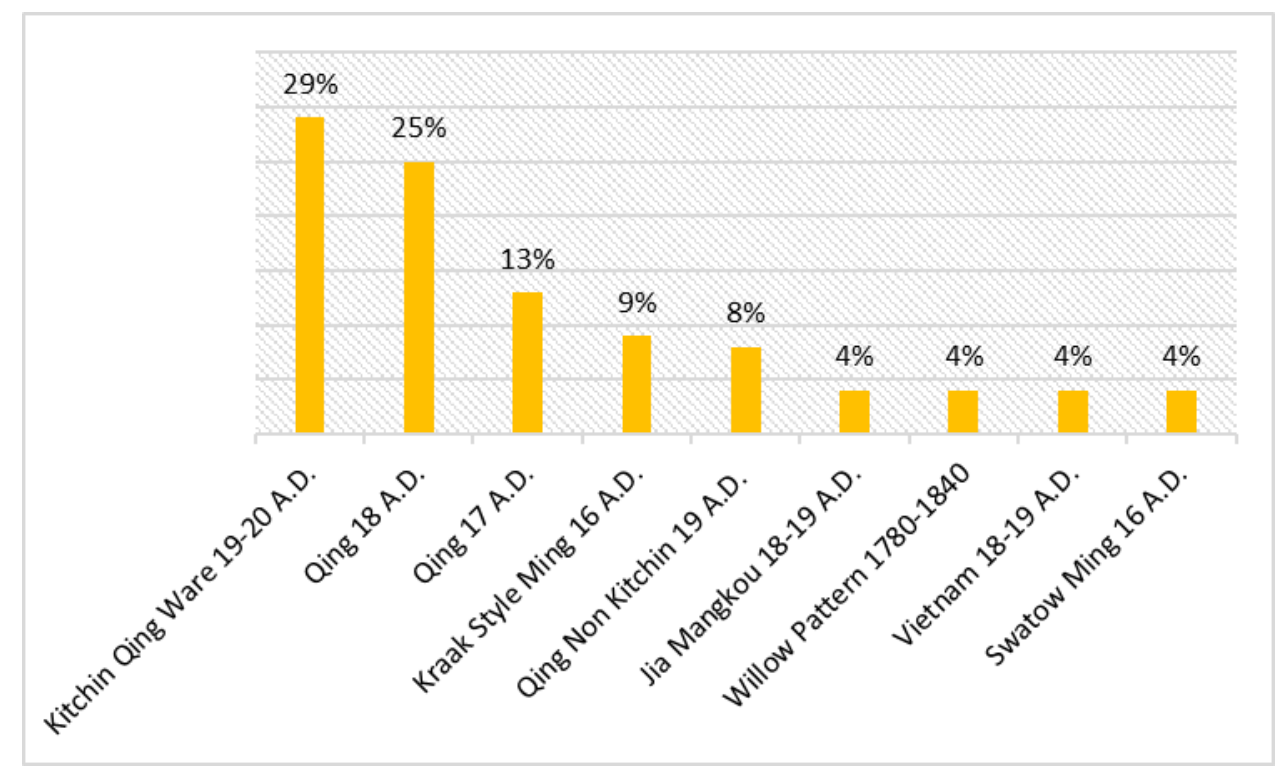

Figure 8. Ceramics Chronology Chart of survey results at Kao Old Village Site (Source: Tim Penelitian, 2014) 


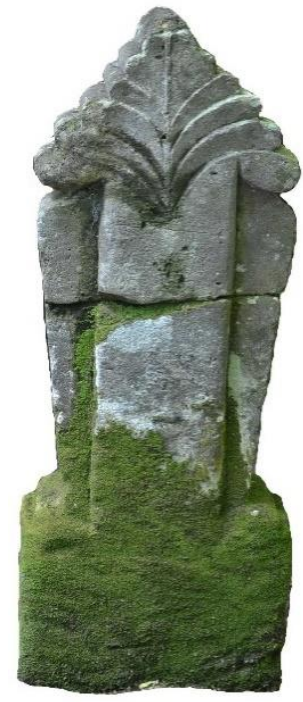

Figure 9. Tombstone typology from the Tomb of Sheikh Mansyur's wife, which shows the typology of a DemakTroloyo gravestone in Java

(Source: Balai Arkeologi Maluku, 2016)

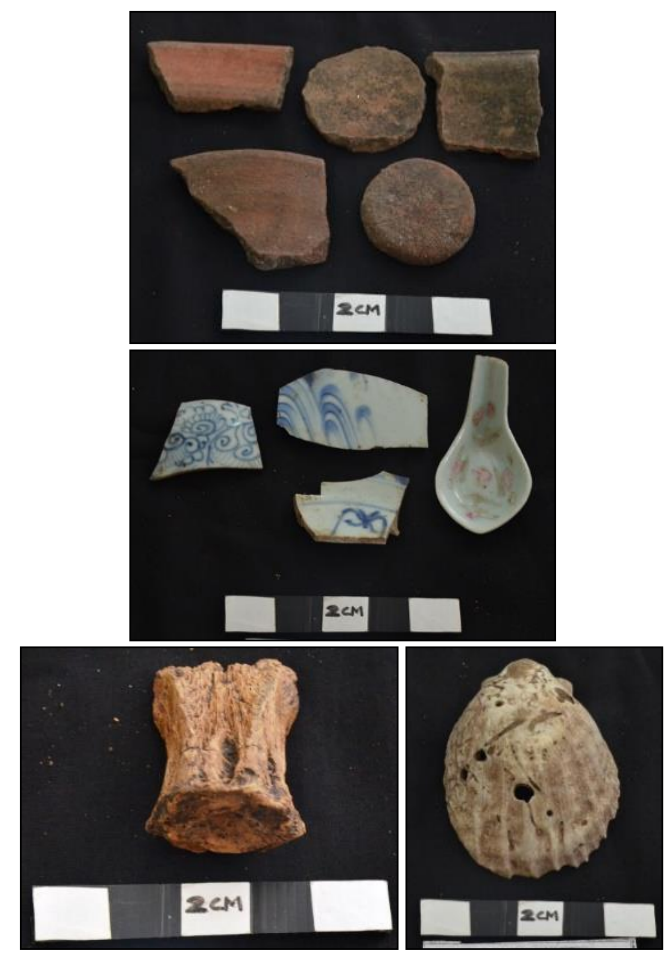

Figure 10. From left to right: Fragment of earthenware findings; ceramics findings from Qing Dynasty 18 A.D. Unidentified bone; shells finding

(Source: Balai Arkeologi Maluku 2016)

traders, both at coastal areas and inland areas (Handoko, 2007: 114).

Earthenware findings and various types of shells from the field survey showed the development of people's activities on the Site. It also explains the intensity of the trading and how the system of exchange of commodity in the region in the past. Earthenware findings show daily household appliances, indicating that life on the Kao Ancient Village is intensive with the use of clay tools which that likely produced in the Kao area itself. Alluvial soil types found in the site area strongly support the production of earthenware tools in the Kao region. In addition, as mentioned before, according to research results Andaya (2015) mention in addition to earthenware from Mare, Kao region is a producer of good quality earthenware. In relation to the findings of various types of mollusks or shells, which are entirely from the sea, indicating occupation and community subsistence on Kao Site one of which comes from marine livelihoods.

\section{Long Term Settlement: Islam Conversion and Ideological Strategy}

Long-term interactions between cultures, here termed cultural engagements (Clarke \& Torrence, 2003), can have more complex effects on settlement patterns. two phenomena tied to cultural engagement are ideological changes, and changes in trade networks. The effect of ideology and ideological change on settlement patterns has attracted attention from archaeologists, especially where such change can be detected in the historical record (e.g. Delle, 1999; González-Ruibal, 2012; Joseph, 1993; Lucas, 2009; McGuire, 1991; Ogundiran, 2014; Rodning, 2011). Beyond the edge of the historical record these investigations become more difficult, but here too archaeologists have identified ideology's effect on settlement patterns (Harrower, 2008; Siegel, 2010) and vice versa (Hutson \& Welch, 2014; Love, 2013). Change in ideology may spur the contestation, abandonment, or destruction of old sacred sites (Bolender, Steinberg, \& Damiata, 2011; Lucas et al. 2009; Oland, 2014). The facts clearly show that in Southeast Asia the first convert to Islam was a coastal trader community. This proves that Islam is a very interesting belief system, which is suitable for increasing the number of Southeast Asian traders. While the spirit of worship, Islamic symbols are universally applicable and easily adapted by the mobility of traders (Lape, 2000b; Lape, 2005; Reid, 1993; Reid, 2011: 151-159). According to Insoll (1996) Islam may have an appeal to agricultural populations (peasants) whose lives are settled and still in animist beliefs and have an interest in mystical and ritual forces (Insoll, 1996: 90-92; Lape, 2000b)

Kao Ancient Village located in the hinterland of North Halmahera is the first inland village that embraces Islam. From Kao Ancient Village then Islam spread to the region along the North Halmahera coast. Although this interpretation still needs to be re-examined, given the lack of similar sites in other remote areas of North Halmahera, but archaeological data and local oral traditions reinforce allegations about the center of Islamicization in the interior, and the existence of a network of trade with the outer regions (Handoko et al., 2016; Handoko, 2017; Handoko \& Mujabuddawat, 2017b; Handoko \& Mujabuddawat, 2017a; Tim 
Penelitian, 2014). Insoll explained that Islamic archeology studies not only focus explicitly on monumental data as religious indicators such as mosques, tombs, inscriptions, artwork, but also include things that potentially affect aspects of life, such as diet, dress, domestic architecture, landscaping, and settlement patterns (Insoll, 2001; Insoll, 2003: 14-22). The oral tradition tells us that the community at Kao Ancient Village has been living since the 16th century and converted to Islam. So far older archaeological data have not been found, further research is needed to find evidence of activity and chronology that can uncover the settlements mentioned in the oral tradition in the Telaga Lina region. Telaga Lina area is probably located in the upper reaches of the watersheds that flow on the Kao Ancient Village. The process of settlement relocation from the Kao Ancient Village in the 16th century to the coast of Kao Village which is inhabited today is a long process. It is estimated that modern Kao Village on the coast has been inhabited since the early 20th century or in 1904, even based on the oral tradition of the local people is older, that is 1880 , as written by van Fraassen (1980). Based on the information, then the occupancy period in Kao Ancient Village between 100 to 200 years. It seems, before inhabiting Kao Ancient Village, the community moved from its original location, Telaga Lina which is unknown location yet then settled for a long-term at Kao Ancient Village. Miksic (2000) and Reid (1988) explains that at the same time, settlements capable of quick relocation could persist in one place for centuries (Miksic, 2000: 116; Reid, 1988: 5). However, the conditions in Kao Ancient Village need to be further investigated, both based on the artifact's sources and its distribution on the surface, as well as the results of archaeological excavations.

Studies in Kao Ancient Village can prove that there are different theories compared to elsewhere in the Maluku Islands. The process of resettlement in almost all of the Maluku Islands was due to Colonial policies in the early 20th century that relocated villages in the inland highlands to coastal areas. De Jonge and Van Dijk (1995) explains the settlement patterns in southeast Maluku. In an effort to create effective oversight of the population, the Dutch ordered to residents whose living in upland villages to move to coastal areas during the first decade of the 20th century. All the settlements located in the highlands are relocated by the Dutch to coastal areas which that inhabited until now to make easier to control all the villages. In some cases of forced relocation, several villages were merged into one village (De Jonge \& Van Dijk, 1995: 28-29). Based on people stories, evidence of ancient mosque features in Kao Ancient Village is believed is the first mosque that was center of Islamic teachings and spreading by Sheikh Mansyur whose came from Baghdad (Handoko, 2017; Handoko \&
Mujabuddawat, 2017b; Manan, 2014: 38). During the colonial occupation, the peoples of Kao Ancient Village were very persistent against the Dutch colonizers, until finally, they moved to the coast in the early 20th century or in 1904 (Handoko et al., 2016; Handoko, 2017; Manan, 2014; Tim Penelitian, 2014). Probably that the Dutch never occupied the Kao Ancient Village area, due to the absence of physical evidence of colonial-characteristic features at the Kao Ancient Village, although the evidence of interaction with the colonial side is quite much indicated by the findings of European ceramics. The environment that supports the development of production sources, especially food sources, has been the motivation of local people in the past to occupy one place for long periods of time. The process of settlement relocation of Kao Ancient Village may be due to various things. Foreign ceramics found in a number of archaeological sites in the Maluku region can mark the hustle and bustle of trade activity in the past (Handoko, 2007: 116). The high movement of settlements from upland to coastal areas in many locations in Maluku is very likely to change the trading environment. Changes in the trading environment may have motivated resettlement to a location more favorable for trade. This explanation reflects the archaeological and historical record of long-distance trade expansion into Eastern Indonesia over the past thousand years (Bulbeck \& Clune, 2003; Lape, 2000a; Leirissa, 1993; Macknight, 1973; Meilink-Roelofsz, 1962; Ptak, 1992; Spyer, 2000; Sutherland, 2000; Swadling et al., 1996; Veth et al., 2000; Veth et al., 2005).

The process of spreading Islam through trade and economic dominance proves that there is a complex mechanism of Islamicization, which may involve of the Ruler. This is an evidence of a highly developed civilization, also giving us an understanding that the spread of Islam through the mechanism of commercial and economic development and the politics of expansionism becomes the chain of Islamic existence itself. In the archipelago of Southeast Asia, including Indonesia, the spread of Islam from Sumatra to the east through trade and conquest lasted from the 13th to the 17 th centuries. The intensively period of Islam conversion in eastern Indonesia is in the 16th century (Reid, 1993: 132). In relation to the Islam conversion strategy, there has been much debate over how Islam is accepted by local people, especially in the Southeast Asian, about whether Islam is accepted by elites or nonelites, which can raising concerns about bias (Lape, 2003).

Political leaders often adopt new religions through existing political processes (e.g. Zoëga \& Bolender, 2017: 71) likewise political or material advantage is often a significant motivator for conversion (Fromont, 2011; Graham et al., 2013). Questions of Islamicization 
ask how Islam came to be accepted and practiced by political leaders and large numbers of their followers. Two basic theoretical approaches guide these questions. One proposes a top-down conversion, in which political leaders drive the large-scale conversion of their followers, while the alternative proposes that Islamicization was a ground-up process, whereby political leaders converted only when sufficient numbers of their subjects were already Muslim. Within these frameworks, there has been considerable debate about the relative role of political Islam and Sufism in relation to the degree to which new Islamic ideas were understandable and sensible to south-east Asians and their diverse pre-existing belief systems (Lape, 2000a; Lape, 2000b; Reid, 1993; Reid, 1995). In Kao Ancient Village, there are clues to the Islamicization strategy that Islam is converted by top-down conversion model, whereby elite or local leader embrace Islam and then followed by the community or their followers. Oral tradition states that Islam was first embraced by a tribal leader and the propagator of Islam, he is Sheikh Mansyur and then teaches Islam, the way is begun by marrying the daughter of tribe leader. The evidence is showed by the long tomb of the Alluk tribe leader, which located in the Kao site. This seems to be a testament to Islamicization strategy applied to the local community at Kao Ancient Village in the past.

The many findings of ancient Islamic tombs, providing knowledge that the old settlement site of Kao is a fairly dense settlement in the past. The arrival of Islam caused a considerable economic impact to the islands of the North Maluku region, including the North Halmahera region. There are many links between the spread of Islam and the development of trade networks.

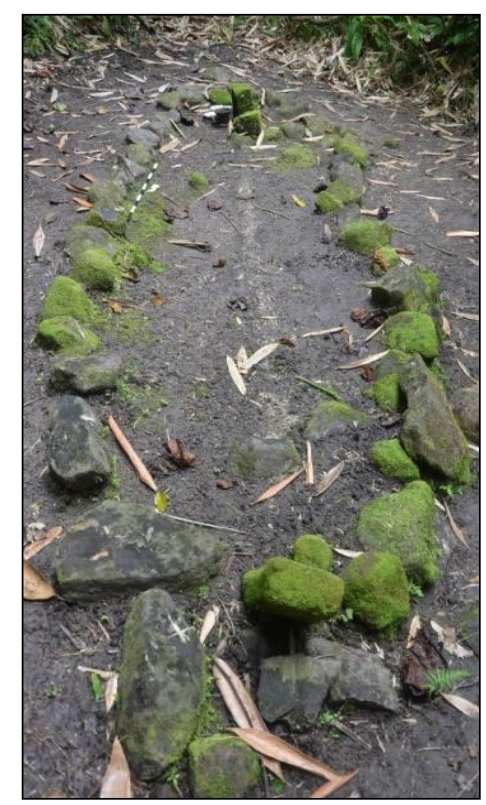

Figure 11. Long tomb of Alluk tribe leader, the first person who embrace Islam in Kao Ancient Village (Source: Balai Arkeologi Maluku, 2016)
This shows how the development of trading posts does not only happen in Ternate but also in Galela and Kao. It seems that Kao's position based on this research has a very important position for the development of Islamic civilization, both its relationship with the political power of Ternate, as well as the position of Kao region itself in the development of Islam in the North Halmahera. It is conceivable how in a remote outback in the river landscape, location in highlands, and wetland forest of sago, people choose a location to live with all the activities that follow there. The Ake Jodo River that extends from the estuary on the coast of Kao is the entrance for migrants and foreign traders to enter the area. Some may also enter through the vast land, which lies to the present west of Kao (Handoko \& Mujabuddawat, 2017b). The Kao community inhabited one location for a long time, apparently also influenced by the arrival of Islam in the region. People easily accept Islam, because of Islam's accommodative attitude toward pre-existing local traditions. Islam that is accommodative to local traditions is a strategy of Islamicization that has occurred in many parts of Indonesia in the past (Handoko, 2012: 27; Mujabuddawat, 2016: 177). Limited occupancy space, making it easier to consolidate in accepting Islam. They gathered in a relatively small enclave, making it easy to meet each other and consolidate. Archaeological data show concentrations of daily tooling artifacts that are concentrated in one or two areas, previously known as Leamanggunung and Tonuo toponyms. In that area the distribution of artifactual data is concentrated. Not far from that location, in the so-called toponym Soa Sio, there is artifactual findings close to a large banyan tree and a number of features allegedly the pole pedestal of the house. On a rather high part of the land, there are features that suggest an early mosque. Twelve stone pedestals remain in a regular pattern on the surface. Below this is a row of burials along the hillside. Archaeological data explain that cluster of Islamic tomb integrates to the settlement.

In the context of the Kao Village, the arrival of Islam further strengthens the community to survive on this site, thus providing an analysis that there can be virtually no resistance of local people who have not previously been religious or just ethnic beliefs, immediately accepting Islam without any significant resistance from the local people. The oral tradition also mentions that the first Muslim propagator, named Syekh Mansyur, bring the Islamic mission in a way that was easily accepted by locals who had previously embraced the religion of their ancestors. Indigenous peoples are communities that consume pig, and Sheikh Mansyur wisely precisely follows the custom of the local people and marries a local woman, the daughter of a tribal leader. The local princess as a term asking to Syekh Mansyur to eat pork meat, if he wish to marry her and convert the local into Islam. 
That term was fulfilled (Handoko et al., 2016; Handoko, 2016: 482; Tim Penelitian, 2014).

The arrival of Islam should be evident in the archaeological record in several ways, one of them by the disappearance of pigs from the faunal assemblage (Lape, 2005: 833). Based on bone findings from excavations, distribution of ancient Islamic-style tombs, as well as a collection of ceramics that can tie them to the chronology of Islam. In the context of Muslim identity, particularly in Southeast Asia, the pattern of pigs consumption is a major marker (Fennell, 1998; Insoll, 1999). Other researchers have concluded that pig avoidance was the most important public marker of Muslim identity in Island Southeast Asia; it would have been a dramatic gesture in a region where pigs are among the most important sources of protein (Groves, 1981; Reid, 1993; Lape, 2005: 833). Pigs abstinence is the most prominent first sign of obedience to Islam (Reid, 2011: 41). In this research, pigs remains have not been discovered and analyzed in depth, but from oral tradition, it seems sufficient to explain the period of the coming of Islam and its development.

The most important Islamic icon and the most obvious marker is the existence of a mosque. Tombs and mosque is the most dominant and important archaeological marker in explaining the Islamic development in the research area. Based on the overall archaeological data in the research area, as an Islam cultural area, shows that mosques and tombs are the most important data in describing how Islam develops in its spreading regions. Especially the mosque became the main icon, or the most specific and obvious marker, how Islam developed in the Maluku region (Handoko, 2014: 25). A mosque can be regarded as an icon or a hallmark of an Islamic Kingdom site, this is because in Islamic tradition since Prophet Muhammad SAW, the

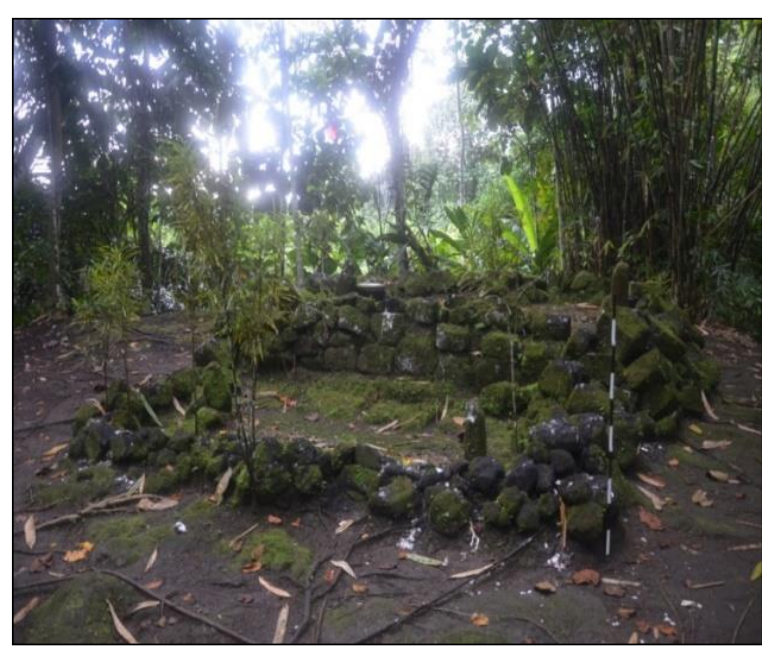

Figure 12. Tomb of Syekh mansyur and his disciple beside (Source: Balai Arkeologi Maluku, 2016)

establishment of the Islamic kingdom is always preceded by the construction of mosques and is considered as a center of activity in all aspects of people's lives (Mahmud, 2003: 40). Thus the mosque is the main symbol of the religiousness of Muslims, the center of orientation and the main source of gaining virtue and knowledge, a part of human inspiration to obtain all the glory as well as the place of purification themselves (Handoko, 2013: 39).

Another than mosque which most important marker on the Islamic site is also the existence of ancient tombs. Discussion about the variety of Islamic archaeological remains, including the ancient tomb is a topic in every discussion about the character and dynamics of Islam in the Indonesian archipelago. Ancient tomb as one of the Islamic features so far has always been associated with how the model of tradition continuity when Islam became a widely converted as a religion of society. This is because the ancient tombs as artifacts and features of Islam can give a description of how the development of

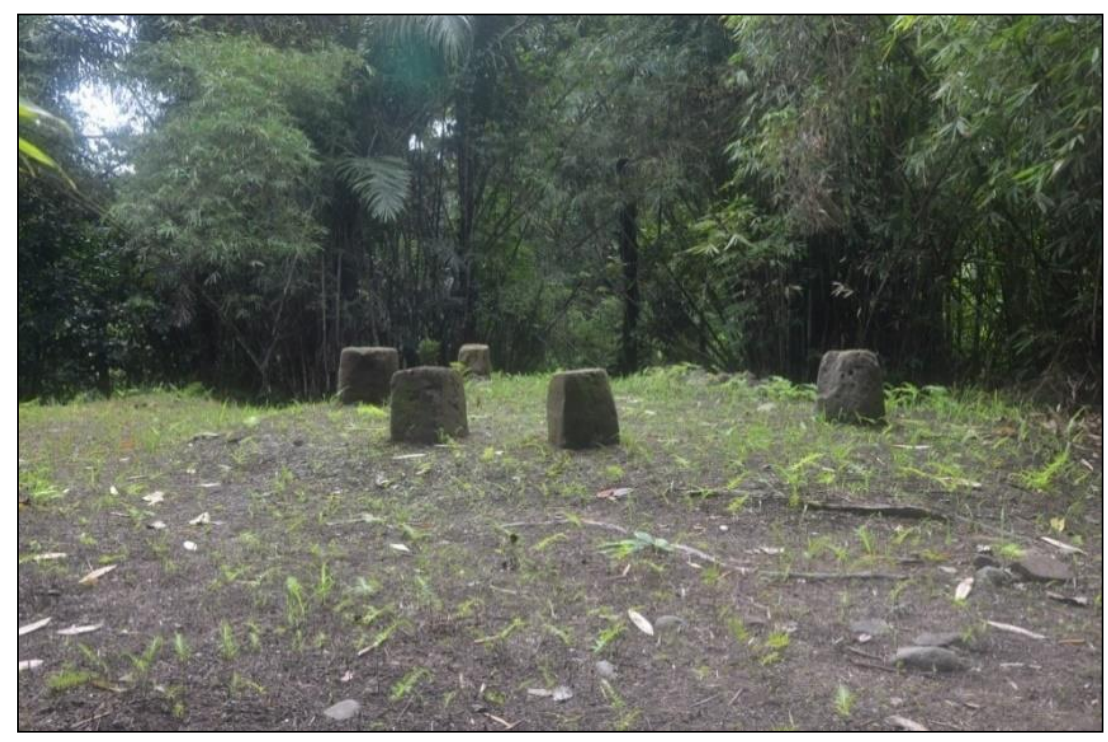

Figure 13. Twelve Poles pedestal of Ancient Mosque features at Kao Ancient Village Site, North Halmahera (Source: Tim Penelitian, 2014) 
acculturation between Islam and the elements of survived local culture. Ambary added, that in the cultural aspects of materials, reflection of socialization of Islam in Indonesian archipelago much influenced by: first, the fact of the historical and social reality at the moment, second: the results of the identification of the basic cultural legitimacy for the admissibility of Islam, and third: the process and strategy of the socialization of Islam which developed locally (Ambary, 1998: 195). This explains that Islam develops because it implements a socialization strategy that adapts the local culture. Before the arrival of Islam, people have known the belief system or religion that existed before the presence of Islam (Handoko, 2014: 34).

The existence of Islamic tombs associated with settlement sites in the same area explains the entry of trade and at the same time the entry of Islam and the attitude of local to accept Islam from the foreigner's traders. Ancient tombs are scattered in the settlement area, utilizing of the remaining limited land. Some of them are separated from the settlement areas. There is artifacts sources in the ancient Islamic tombs and nonIslamic tombs in minimal numbers, this indicates that in Kao Village there is no clear spatial separation between the settlements and the tombs. The residential locations are more concentrated in areas which close to water sources and relatively close together. This shows that the consolidation strategy of the community is well maintained and regular.

Another ideological strategy is shown by the presence of twelve mosque pole pedestals, in this case, the mosque is a factor that maintains the existence of the settlement. Related to the discussion of resettlement or relocated settlement by impermanence and moveable property houses, it appears that the Kao mosque features show more permanent features. The pole pedestals of the mosque are made from heavy stones type and amounted to tens, with the process of quite complicated at that time, can not be left or carried to then build a new settlement. It gives the analysis that the design of mosques with big stone pole pedestals is a factor that encourages people to survive there, amid limited space conditions and the threat of flooding overflowing river water in the rainy season.

This study suggests that the arrival of Islam in Kao Ancient Village did not affect the composition of the previous settlement. This differs from the influence of Islam on the change of settlement pattern in some other cases in Maluku, Indonesia and in Africa, as Lape (2000b) described in Banda and Insoll (2001) in Africa. Although the practice of adaptation and syncretism must occur. According to historical records and oral traditions, that is mentioned at the time of settling on this site, the number of Kao peoples is only about 100 people, so in terms of quantity, it makes sense if all embrace Islam and settle in the same place, no need for separation of residential location. There are also clues from the archaeological data on makam bulat (round tombs) that is a non-Islamic tomb but located mixed with Islamic tombs and also close to the settlement. This archaeological evidence further reinforces the explanation that in the context of the people of the Kao Ancient Village in the past that conversion to Islam is a 'collective obedience'. The actual archaeological data can also explain this phenomenon. The distribution of ancient Islamic tombs scattered among the settlement spaces is the most factual evidence that Islam is a communally accepted religion. The existence of very few non-Islamic tombs that are located associated with the Islamic tombs, it becomes evident that there is no separation between the people who convert Islam with indigenous people who still follow the religion of their ancestors.

This evidence differs from the results of studies elsewhere, in which Islamic migrants may established an enclave which eventually mixed with the indigenous community (Insoll, 2001; Lape, 2000b). The pattern Lape (2000b) identified in the Banda Islands conforms to a three-stage process that Insoll (2003) describes from sub-Saharan Africa, wherein a separate population of Islamic newcomers is first "quarantined" in a separate settlement, then their religion then mixes syncretically with the local religion, and finally this syncretism hews closer to a global Islamic orthodoxy. On the contrary, in the case of the Kao site, in view of the limited occupancy space and the abundant resource potential, there is no indication that there is a separation between those who accept and those who reject Islam, perhaps reinforcing the idea that the site's residents accepted Islam immediately.

\section{Conclusion}

Archaeological evidence in Kao Ancient Village site explains that Kao land is one of the centers of Islamic civilization in North Halmahera, whereby from there Islam spreading to other areas along the coast of North Halmahera. Thus, based on the environmental carrying capacity of the site, it is explained that the Kao site which is not much recorded in historical sources, as a residential area of the Islamic community, actually has a significant role as the center of Islamicization in Halmahera. The lush river basin with wetland and farming characteristic is the determining factor of the Kao region to be a very developed settlement, even in the process of spreading Islam. Given the path of Islamicization and trade, it also places the region as a significant link in connecting Ternate as the center of Islamic power with other regions in North Halmahera. It can be concluded that the selection of settlement location 
in the hinterland of Kao, and long-term settlements, supported by water sources and the potential of farming lands, is part of the strategy of local people in the process of spreading Islam to other inland areas, as well as coastal areas. For this thesis still needs archeological evidence to find other Islamic sites in the hinterland along the watersheds of Kao and North Halmahera in general.

\section{ACKNOWLEDGEMENT}

The authors would like to thank all those who have supported this research, both during field data collection and post-analysis. Thanks to the help of various parties, finally achieved to publish this paper as part of Kao article that has been published previously. Hopefully, this publication can be beneficial and provide scientific impact.

\section{$* * * * *$}

\section{REFERENCES}

Amal, M. A. (2010). Kepulauan Rempah-rempah Perjalanan Sejarah Maluku Utara 1250-1950. Jakarta: Kepustakaan Populer Gramedia (KPG).

Ambary, H. M. (1998). Menemukan Peradaban, Arkeologi dan Islam di Indonesia. Jakarta: Pusat Penelitian Arkeologi Nasional.

Andaya, L. Y. (1991). Local Trade Networks in Maluku in the 16th, 17th and 18th Centuries. Cakalele, 2(2), 71-96.

Andaya, L. Y. (1993). The world of Maluku: Eastern Indonesia in the early modern period. Honolulu: University of Hawaii Press.

Andaya, L. Y. (2015). Dunia Maluku Indonesia Timur Pada Zaman Modern Awal. Yogyakarta: Ombak.

Binford, L. R. (1990). Mobility, Housing, and Environment: A Comparative Study. Journal of Anthropological Research, 46(2), 119-152.

Bolender, D. J., Steinberg, J. M., \& Damiata, B. N. (2011). Farmstead relocation at the end of the Viking Age: results of the Skagafjörhur archaeological settlement survey. Archaeologica Islandica, 9, 77-99.

Bulbeck, F. D., \& Clune, G. (2003). Macassar Historical Decorated Earthenwares: Preliminary chronology and Bajau connections. In Earthenware in Southeast Asia (pp 80-102).

Campen, C. F. H. (1883). Het eiland Halmahera. Tijdschrift van Het Bataviaasch Genootschap, 28, 240-313.

Carvajal, J. C. (2013). Islamicization or Islamicizations? Expansion of Islam and social practice in the Vega of Granada (south-east Spain). World Archaeology, 45(1), 109-123.

Clarke, A., \& Torrence, R. (2003). The Archaeology of Difference: negotiating cross-cultural engagements in Oceania. London: Routledge.

De Jonge, N., \& Van Dijk, J. (1995). Forgotten Islands of Indonesia: The Art \& Culture of the Southeast Moluccas. Tuttle Publishing, 2012. Singapore: Periplus.

Delle, J. A. (1999). The Landscapes of Class Negotiation on Coffee Plantations in the Blue Mountains of Jamaica: 1790-1850. Historical Archaeology, 33(1), 136-158.
Denham, T., Haberle, S., \& Lentfer, C. (2004). New Evidence and Revised Interpretations of Early Agriculture in Highland New Guinea. Antiquity, 78(302), 839-857.

Ellen, R. F. (1979). Sago Subsistence and the Trade in Spices: a Provisional Model of Ecological Succession and Imbalance in Moluccan History. In P. C. Burnham (Ed.), Social and Ecological Systems (pp. 43-74). London: Academic Press.

Ellen, R. F. (2003). On the Edge of the Banda Zone: Past and Present in the Social Organization of a Moluccan Trading Network. Honolulu: University of Hawaii Press.

Fennell, C. (1998). Conjuring Boundaries: inferring past identities from religious artifacts. International Journal of Historical Archaeology, 4(4), 281-313.

Fromont, C. (2011). Under the sign of the cross in the kingdom of Kongo: religious conversion and visual correlation in early modern Central Africa. RES: Anthropology and Aesthetics, 59(1), 109-123.

González-Ruibal, A. (2012). From the battlefield to the labour camp: archaeology of civil war and dictatorship in Spain. Antiquity, 86(332), 456-473.

Graham, E., Simmons, S. E., \& White, C. D. (2013). The Spanish conquest and the Maya collapse: how "religious" is change? World Archaeology, 45(1), 161-185.

Groves, C. (1981). Ancestors for the pigs: taxonomy and phylogeny of the genus sus. Canberra: Australian National University.

Handoko, W. (2007). Aktifitas Perdagangan Lokal di Kepualuan Maluku Abad 15 M - 19 M, Tinjauan Awal Berdasarkan Data Keramik Asing dan Komoditas Lokal. Kapata Arkeologi, 3(4), 100-120.

Handoko, W. (2012). Perkembangan Islam di Pulau Ambalau: Kajian atas Data Arkeologi dan Tradisi Makam Islam Berundak. Kapata Arkeologi, 8(1), 25-34.

Handoko, W. (2013). Karakteristik Arsitektur Masjid Kuno dan Perkembangan Islam di Maluku. Amerta, 31(1), 3952.

Handoko, W. (2014). Tradisi Nisan Menhir pada Makam Kuno Raja-raja di Wilayah Kerajaan Hitu. Kapata Arkeologi, 10(1), 33-46.

Handoko, W. (2016). The Continuity of Austronesian Tradition on Islamic and Early Colonial Period in Maluku. In B. Prasetyo, T. S. Nastiti, \& T. Simanjuntak (Eds.), Proceedings the International Symposium on Austronesian Diaspora (pp. 481-491). Yogyakarta: Gadjah Mada University Press.

Handoko, W. (2017). Ekspansi Kekuasaan Islam Kesultanan Ternate di Pesisir Timur Halmahera Utara. Kapata Arkeologi, 13(1), 95-108.

Handoko, W., \& Mujabuddawat, M. A. (2017a). Lingkungan dan Lansekap Situs Kampung Kuno Kao: Faktor Determinasi Permukiman dan Pusat Islamisasi di Halmahera Utara. KALPATARU, Majalah Arkeologi, 26(2), 123-136.

Handoko, W., \& Mujabuddawat, M. A. (2017b). Situs Kampung Tua Kao: Identitas Asal Usul dan Jejak Peradaban Islam di Wilayah Pedalaman Halmahera Utara. Jurnal Pendidikan Dan Kebudayaan, 2(2), 150-165.

Handoko, W., Mujabuddawat, M. A., Huwae, A., Husni, M., Karolina, J., \& Latupapua, S. (2016). Research report: Tanah Kao: Menguak Identitas Asal Usul Komunitas, Sejarah, dan Peradaban Islam di Halmahera Utara. Ambon: Balai Arkeologi Maluku.

Harrower, M. J. (2008). Hydrology, Ideology, and the Origins of Irrigation in Ancient Southwest Arabia. Current Anthropology, 49(3), 497-510.

Hutson, S. R., \& Welch, J. A. (2014). Sacred Landscapes and Building Practices at Uci, Kancab, and Ucanha, Yucatan, Mexico. Ancient Mesoamerica, 25(2), 421-439. 
Insoll, T. (1996). Introduction. The Archaeology of World Religion. In T. Insoll (Ed.), Archaeology and World Religion. London: Routledge.

Insoll, T. (1999). The Archaeology of Islam. Oxford: Blackwell.

Insoll, T. (2001). The Archaeology of Islam. In Archaeology and World Religion (pp. 123-147). London: Routledge.

Insoll, T. (2003). The Archaeology of Islam in Sub Sahara Africa. Cambridge: Cambridge University Press.

Joseph, J. W. (1993). White Columns and Black Hands: Class and Classification in the Plantation Ideology of the Georgia and South Carolina Lowcountry. Historical Archaeology, 27(3), 57-73.

Kayser, M., Brauer, S., Weiss, G., Underhill, P., Roewer, L., Schiefenhövel, W., \& Stoneking, M. (2000). Melanesian origin of Polynesian Y chromosomes. Current Biology, 10(20), 1237-1246.

Lape, P. V. (2000a). Contact and Colonialism in the Banda Islands, Maluku, Indonesia. Bulletin of the Indo-Pacific Prehistory Association 4, 20(4), 48-55.

Lape, P. V. (2000b). Political Dynamics and Religious Change in the Late Pre-colonial Banda Islands, Eastern Indonesia. World Archaeology, 32(1), 138-155.

Lape, P. V. (2003). A Highway and a Crossroads: Island Southeast Asia and Culture Contact Archaeology. Archaeology in Oceania, 38(2), 102-109.

Lape, P. V. (2005). Archaeological approaches to the study of Islam in Island Southeast Asia. Antiquity, 79(306), 829 836.

Leirissa, R. Z. (1990). Masyarakat Halmahera dan Raja Jailolo: Studi tentang Sejarah Masyarakat Halmahera Utara. Thesis Universitas Indonesia.

Leirissa, R. Z. (1993). The Structure of Makassar Bugis Trade in Premodern Moluccas. In Review of Indonesian and Malaysian Affairs 27 (p. 77).

Love, S. (2013). Architecture as Material Culture: Building Form and Materiality in the Pre-Pottery Neolithic of Anatolia and Levant. Journal of Anthropological Archaeology, 32(4), 746-758.

Lucas, G. (2009). The Tensions of Modernity: Skálholt During the 17th and 18th Centuries. Journal of the North Atlantic 2(sp1), 75-88.

Lucas, G., Batey, C., Gudmundsson, G., Lawson, I. T., Mc Govern, T. H., \& Simpson, I. A. (2009). Hofstahir: excavations of a Viking Age feasting hall in north-eastern Iceland. Reykjavik: Institute of Archaeology.

Macknight, C. C. (1973). The Nature of Early Maritime Trade: some points of analogy from the eastern part of the Indonesian archipelago. World Archaeology, 5(2), 198208.

Mahmud, M. I. (2003). Kota Kuno Palopo: dimensi fisik, sosial, dan kosmologi. (M. Press, Ed.). Makassar.

Manan, M. A. (2014). Ritual Tagi Jere dalam Komunitas Etnik Kao: Peran Lembaga Dewan Adat dan Badan Syara' dan Perkembangannya. Jurnal Masyarakat \& Budaya, 16(1), 27-50.

McGuire, R. (1991). Building Power in the Cultural Landscapes of Broome County, New York 1880 to 1940. In The Archaeology of Inequality (pp. 102-124).

Meilink-Roelofsz, M. A. P. (1962). Asian Trade and European Influence in the Indonesian Archipelago between 1500 and about 1630. Ph.D. Dissertation, Nijhoff The Hague.

Miksic, J. N. (2000). Heterogenetic Cities in Premodern Southeast Asia. World Archaeology, 32(1), 106-120.

Mujabuddawat, M. A. (2015). Kejayaan Kesultanan Buton Abad ke-17 \& 18 dalam Tinjauan Arkeologi Ekologi. Kapata Arkeologi, 11(1), 21-32.

Mujabuddawat, M. A. (2016). Simbolisme Kompleks Bangunan Situs Ki Buyut Trusmi Cirebon. Kapata Arkeologi, 12(2), 175-190.
Naping, H. (2013). Halmahera Utara, Sejarah Perkembangan Peradaban di Bumi Hibua Lamo. Makassar: Universitas Hasanuddin, Pemerintah Kabupaten Halmahera Utara, dan Yayasan Bina Generasi.

O'Connor, S. (2006). Unpacking the Island Southeast Asian Neolithic cultural package, and finding local complexity. In Uncovering Southeast Asia's Past (pp. 74-86).

Ogundiran, A. (2014). The Making of an Internal Frontier Settlement: Archaeology and Historical Process in Osun Grove (Nigeria), Seventeenth to Eighteenth Centuries. African Archaeological Review, 31(1), 1-24.

Oland, M. (2014). With the Gifts and Good Treatment That He Gave Them: Elite Maya Adoption of Spanish Material Culture at Progresso Lagoon, Belize. International Journal of Historical Archaeology, 18(4), 643-667.

Poelinggomang, L., E. (2002). Makassar Abad XIX. Jakarta: Kepustakaan Populer Gramedia (KPG).

Ptak, R. (1992). The Northern Trade Route to the Spice Islands : South China Sea - Sulu Zone - North Moluccas (14th to early 16 th century). Archipelago, 43(1), 27-56.

Ptak, R. (1999). China's Seaborne Trade With South and Southeast Asia 1200-1750. Farnham: Ashgate Publishing.

Reid, A. (1988). Southeast Asia in the Age of Commerce, 14501680, volume one: The lands below the winds. New Haven: Yale University Press.

Reid, A. (1993). Southeast Asia in the Age of Commerce, 1450 1680, volume two: Expansion and crisis. New Haven: Yale University Press.

Reid, A. (1995). Continuity and change in the Austronesian transition to Islam and Christianity. In P. Bellwood, J. Fox, \& D. Tryon (Eds.), The Austronesians: historical and comparative perspectives (pp. 314-318). Canberra: Australian National University.

Reid, A. (2011). Asia Tenggara Dalam Kurun Niaga 14501680 Jilid 2 Jaringan Perdagangan Global. Jakarta: Yayasan Pustaka Obor Indonesia.

Rodning, C. B. (2011). Mortuary Practices, Gender Ideology, and the Cherokee Town at the Coweeta Creek Site. Journal of Anthropological Archaeology, 30(2), 145-173.

Siegel, P. E. (2010). Continuity and Change in the Evolution of Religion and Political Organization on Pre-Columbian Puerto Rico. Journal of Anthropological Archaeology, 29(3), 302-326.

Spriggs, M. (2011). Archaeology and the Austronesian expansion: where are we now? Antiquity, 85(328), 510 528.

Spyer, P. (2000). The Memory of Trade: Modernity's entanglements on an eastern Indonesian island. Durham: Duke University Press.

Stark, K., \& Latinis, K. (1992). The Archaeology of Sago Economies in Central Maluku: An Initial Sketch. Cakalele, 3, 69-86.

Stark, K., \& Latinis, K. (1996). The Response of Early Ambonese Foragers to the Maluku Spice Trade: The Archaeological Evidence. Cakalele, 7, 51-76.

Sutherland, H. (2000). Trepang and Wangkang: The China trade of eighteenth-century Makassar c. 1720s-1840s. Bijdragen Tot de Taal-, Land-En Volkenkunde, 156(3), 451-472.

Swadling, P., Wagner, R., \& Laba, B. (1996). Plumes of Paradise: trade cycles in outer Southeast Asia and their impact on New Guinea and nearby islands until 1920. Honolulu: University of Hawaii Press.

Szabó, K., \& O'Connor, S. (2004). Migration and Complexity in Holocene Island Southeast Asia. World Archaeology, 36(4), 621-628.

Tanudirjo, D. A. (2006). The Dispersal of Austronesianspeaking People and the Ethnogenesis of Indonesian People. In Austronesian Diaspora and the Ethnogeneses of People in Indonesian Archipelago (pp. 83-98). 
Terrell, J. E. (1988). Prehistory in the Pacific Islands. Cambridge: Cambridge University Press.

Tim Penelitian. (2014). Laporan penelitian: Arkeologi Islam di Wilayah Pesisir Timur Kabupaten Halmahera Utara. Ambon: Tidak terbit.

van Fraassen, C. F. (1980). Types of socio-political structure in North Halmaheran history. Indonesia Circle, 8(23), 2139.

Veth, P. M., O’Connor, S., Spriggs, M., Nayati, W., Jatmiko, A., \& Husni, M. (2000). The Mystery of the Ujir Site: insights into the early historic maritime settlement of the Aru Islands, Maluku. Bulletin of the Australian Institute for Maritime Archaeology, 24, 125.

Veth, P. M., O'Connor, S., Spriggs, M., Nayati, W., Jatmiko, A., \& Husni, M. (2005). The Ujir Site: An Early Historic Maritime Settlement in Northwestern Aru. The Archaeology of the Aru Islands, Eastern Indonesia. Terra Australis, 22, 85-93.

Zoëga, G., \& Bolender, D. (2017). An archeology of moments: Christian conversion and practice in a medieval household cemetery. Journal of Social Archaeology, 17(1), 69-91. 